\title{
"AND THE IMAGE OF THE EMPEROR [...] I HAVE TORN IT INTO A THOUSAND PIECES." MENTAL FRONTIERS IN THE NĂSĂUD REGION AT THE END OF THE GREAT WAR
}

\author{
Claudia Septimia SABĂU \\ Babeş-Bolyai University, Academic Cultural Heritage Department, University History Museum, and Territorial \\ Identities and Development Research Centre, Cluj-Napoca, ROMANIA \\ claudia.sabau@ubbcluj.ro \\ DOI: http://doi.org/10.23740/TID220204
}

\section{ABSTRACT}

The First World War and the events concluding 1918, namely the unification of Transylvania with the old Kingdom of Romania, changed not only the geographical frontiers of the former Austrian-Hungarian province, but also the mental ones, which are less evident from the official documents of the era. The purpose of our exploratory study is to use edited archival documents, memoirs, and parochial chronicles in order to reconstruct the local context in which the transition from the 'old' to the 'new order' unfolded. The study focuses on a clearly delimited geographical area with a distinctive historical evolution: the region of Năsăud. Using the memoirs of veterinarian Pavel Tofan as a case study, we focused on identifying the symbolic gestures which mentally transformed the inhabitants of this region from loyal subjects of the Emperor in Vienna to Romanian citizens, loyal to the King of United Romania.

Keywords: Transylvania, 1918, memoirs, dynastic loyalty, Năsăud military border guards

Cite this article as: Sabău, C.S. (2020). "And the Image of the Emperor [...] I Have Torn It into a Thousand Pieces." Mental Frontiers in the Năsăud Region at the End of the Great War. Territorial Identity and Development, 5(2), 64-77. DOI: http://doi.org/10.23740/TID220204

\section{INTRODUCTION}

The First World War and the events concluding 1918, namely the organisation of the Great National Assembly of Alba-Iulia and the unification of Transylvania with the old Kingdom of Romania, are well-known from a political, national and military perspective. As a result of these developments, not only the geographical borders of Transylvania were re-configurated, but also the mental frontiers of this region's inhabitants.

Given the multi-ethnic and multi-confessional character of the province which belonged to the Habsburg Monarchy until 1867 and thereafter to its Austrian-Hungarian continuator, reconstructing the way in which the various communities integrated mentally in the new Romanian state represents a challenge. How was the mental frontier overcome by the Transylvanian Romanians considering it had been consolidated through a lengthy period of obedience towards the Emperor in Vienna and the authorities in Budapest? What were the symbolic gestures identified in the transitional process towards the 'new order'? To find the answers to these questions, we launched an exploratory analysis focused on the region of Năsăud, based on the memoirs of veterinarian PavelTofan, a man directly involved in the local 
reorganisation during the first half of November $1918 .{ }^{1}$ The choice of this case study is not accidental, being motivated by the distinctive historical evolution of this region.

Under the terms of 'Năsăud region', 'Năsăud lands' or 'Năsăud villages' we refer to the 44 communities which were part of the Romanian Border Regiment II, that had its headquarters in Năsăud between 1762 and $1851 .{ }^{2}$ This region was part of the Habsburg system of frontiers, extending from Austria to the North-East of Transylvania. The Năsăud 'grăniceri' (military border guards), in their majority Greek-Catholic peasants, were a special social class in Transylvania and, during the nearly 100 years in which the frontier institution operated, they were considered a privileged category of Romanianethnics. They were granted this special status through the House of Habsburg decrees and the military specific of the region was visible both at the internal level of the community (as daily life was conditioned by military rigours) and the external level (men participated in military campaigns on the European battlefields). Thus, the inhabitants of the Năsăud villages developed the so-called 'fală' (pride) or military border guards' mentality, traces of which can be noticed even to these days. The military border guards' faith in the Emperor, whom they regarded as the guarantor of their enhanced rights and freedoms, constituted, according to historian Liviu Maior, a sense of "dynastic patriotism" (Maior, 2004, p. 58).

Following the abolition of the Transylvanian border system in 1851, the military administration was replaced with a civilian one and the frontier villages were re-organised in administrative circles under the authority of foreign civil servants. From 1861 to 1876, in the context of the inauguration of a liberal governance in the Habsburg Monarchy, the former military border guards' lands were regrouped into the so-called District of Năsăud, ${ }^{3}$ suggestively defied by a contemporary as "a compact body, a natural complex composed from purely Romanian communities, with their fortunes, their funds, their language [...] a historical individuality" (Lupșan \& Onofreiu, 2003, p. 30). In this context, the descendants of the military men of Năsăud continued to harbour a sense of loyalty for the Emperor in Vienna, while displaying the same attitude of superiority in relation to the other inhabitants of the province. These characteristics led to the development of one of the best outlined local and regional identities in Transylvania (Mitu, 2016; Sabău, 2015; llovan, 2009).

Following the dismantling of the District of Năsăud, the 44 communities became part of BistrițaNăsăud County (Comitat), with residency in Bistrița, situation which lasted until 1918. During the First World War, this territory did not become a battlefield, but was in the vicinity of the frontlines.

${ }^{1}$ The manuscript of the memoirs is kept by the Bistrița-Năsăud County Service of the Romanian National Archives. However, the memoirs were published by Andreea Salvan (cf. Salvan, 2008).

2 The 44 communities were distributed alongside four important valleys: the Someșul Mare River and its tributary streams (Rodna Nouă or Șanț; Rodna Veche; Maieru; Ilva Mare; Sângeorz-Băi; Sâniosif or Poiana Ilvei; Măgura Ilvei; Leșu; Ilva Mică; Feldru; Rebrișoara; Rebra; Nepos; Parva; Năsăud; Salva; Hordou or Coșbuc; Telciu; Bichigiu; Romuli; Zagra; Poienile Zagrei; Găureni; Suplai; Mocod; Runc; Mititei), Bârgău (Tiha Bârgăului; Prundu Bârgăului; Mureșenii Bârgăului; Bistrița Bârgăului; Josenii Bârgăului; Susenii Bârgăului; Rusu Bârgăului; Mijlocenii Bârgăului), Șieu (Nușfalău; Sântioana; Budac; Gledin; Monor; Ragla; Șieuț) and Mureș (Morăreni and Rușii Munți). Of these localities, Năsăud was chosen as the residence of the Regiment's commander and, as a consequence, this town became the administrative, religious and cultural centre of the region. Năsăud maintained and consolidated its status throughout the second half of the $19^{\text {th }}$ century.

${ }^{3}$ For more details about the creation and functioning of the District of Năsăud, see Onofreiu, 2010. 
Remembering the unfolding of events at the end of 1918, Bistrița journalist Gustav Zikeli recounted in his autobiography: "After hundreds of years of belonging to Hungary, we became Romanian citizens" (Morariu, 2018, p. 51). Paraphrasing Zikeli's words, the purpose of our study is to use edited archival documents, memoirs, and parochial chronicles in order to reconstruct the local and regional context and to identify the moment when the transition from the 'old' to the 'new order', from loyalty towards the Emperor in Vienna to loyalty towards the King of United Romania took place. The dynastic loyalism showed to the House of Habsburg was an argument invoked by the political elite of Năsăud throughout the $19^{\text {th }}$ century. Moreover, the faith in the Emperor was also a constant in the collective mentality of the common, simple people. Veterinarian Pavel Tofan's memoirs will help us identify the symbolic gestures which transformed, at the end of the Great War, the inhabitants of the addressed space from subjects of the Austrian-Hungarian Empire into Romanian citizens.

\section{THEORETICAL BACKGROUND}

According to the dictionary definition, a frontier is "the natural or conventional line which separates the territory of a state from the territory of other states or stretches of water that are not part of its territory," while figuratively it means "the limit between two distinct things" (blaurb, 2020). In the views of researchers Ștefan Purici, Harieta Mareci and Dumitru Vitcu, apart from delimitating the territory of one state from the territory of another, frontiers can also have "configurative functions" when they shape mental or affective processes. There are various mental constructions of space and, at the same time, of the frontiers which delimitate that space - such as barriers, age limits, eligibility criteria, ethnic or religious affiliation, etc. However, according to the aforementioned authors, all these mental constructions possess so-called "forms of passage," which establish the condition and manner in which the frontier transition can take place - for example border control, interethnic or intercultural dialogue, initiation rites (Purici, Mareci \& Vitcu, 2005, p. 173). The authors underline that, although the subject of "frontiers" can be addressed from multiple, interdisciplinary perspective, during the last 30 years, most of the Romanian historians focused primarily on the frontiers' capacity of preserving national identity, or in order to explain a series of cultural clashes or relations (Purici, Mareci \& Vitcu, 2005, pp. 173-174).

The historians Vasile Vese and Crina Capotă share similar views. They consider that the theme of frontiers and identity is addressed in the post-1989 Romanian historiography almost exclusively with a focus on political and national frontiers. Priority is given to the diplomatic, economic, and cultural relations with the neighbouring states, in particular to those at the West and East of Romania (Vese \& Capotă, 2005, pp. 164-166). The two researchers note that, along the years, most historians sought only to justify and legitimise the frontiers of inter-war Romania, showing a gross lack of diversity. This shortcoming is also noticeable at a methodological level as, most of the times, the works addressing the topic of frontiers, were not approached interdisciplinary and do not link history with its related fields, such as anthropology or ethnography (Vese \& Capotă, 2005, p. 167).

Given the opinions previously presented, we consider that the theme of 'mental frontiers' can be extremely attractive and relevant for historians, particularly for those interested in the First World War. Why so? Because the major changes in everyday life, those of a political, administrative, educational, and territorial nature that took place during the years of conflagration and which peaked at the end of 1918, also led to an unprecedented redrawing of mental frontiers. 
In the context of the Centenary of the Great War, the autochthonous historiography was enriched with many works capturing various social-cultural aspects in the life of communities during wartime (see for example Tămaș, 2015; Bolovan, Cojocaru \& Tămaș, 2015). In recent years, in historical writing, a new approach of the 1914-1918 events was attempted, which is fully in line with the latest methodological perspectives seen in international historiography (Winter \& Sivan, 2006; Horne, 2010; Winter, 2014; Hämmerle, Überegger \&Zaar Bader, 2014). For example, the memoires of the World War One (Leu, Bocșan \& Bedecean, 2012-2015), the quantification of the impact of war on the demographic realities of Transylvania (Bolovan, 2015), as well as the consequences of official propaganda in favour of mobilising support towards the efforts of war (Ignat Kisanovici, 2015; Sima \& Mihalache, 2018) were analysed.

Recently, the geographical space addressed in our study has also benefited from the publication of works which presented formerly unedited primary sources referring to the 'home front' (Onofreiu \& Vlașin, 2017), the 'way of things' throughout 1918 (Onofreiu, Pintea \& Vlașin, 2018), or the memory of war and revolution (Dăncilă Ineoan, 2015), following a line of research inaugurated by Eugenia Bârlea (Bârlea, 2004).

In order to identify the perception of common people - the collective memory of different communities - the parochial chronicles are extremely valuable. In what the Năsăud villages are concerned, to this date, the chronicles of the following localities were identified and published: Bistrița Bârgăului, Mureșenii Bârgăului, Rebrișoara and Șieu (Buta \& Onofreiu, 2010, doc. 35, pp. 280-282; Onofreiu, 2008, doc. 1, pp. 43-49; Onofreiu \& Vlașin, 2017, doc. 257, pp. 275-282; doc. 258 , pp. 283-294). Through the voices of priests, whose discourses were as eloquent as the writing talent each of them possessed, the content of these chronicles offer "rough accounts of the four years of conflict," being one of the most important sources for drawing the outline of the Năsăud peasant world during the conflagration (On ofreiu, 2019, p. 173). To these, one can add the joumal kept by Pamfiliu Grapini, the priest of Șanț, with the mentioning that this historical source both precedes and goes beyond the temporaryspan of the Great War (Grapini, 2018).

To round out the information gathered from the aforementioned sources, the memoirs and journals of contemporaries are very useful, especially towards reconstructing the events of November-December 1918. In describing the Năsăud communities during the analysed period of time, the most valuable such sources are those signed by veterinarian Pavel Tofan, as they are reach in symbolic and behavioural details (Salvan, 2008, pp. 69-108).

\section{METHODOLOGY}

The analysed historical sources are diverse, reason why the research methods were applied to the specific of each. In consequence, the study applied a qualitative research methodology, primarily centred on descriptive analysis and discourse analysis, both based on critique and interpretation. The volumes of edited documents, corroborated with the parochial chronicles, the monographies of various localities and the other bibliographic sources will help us outline the general framework at the end of 1918 - the face of the 'old order'. Pavel Tofan's memoirs will stand as the basis for reconstructing the specific way in which the simple people overcame or were helped to overcome certain mental frontiers in order to make the transition towards a new reality, a new world order. Nevertheless, we did not lose sight of the fact that the memoir genre involves a high degree of subjectivism and the described events were filtered through the subjective perspective of our source's author. 


\section{RESULTS AND DISCUSSION}

\section{The face of the 'old order'. The Năsăud villages at the end of the Great War}

Until the outbreak of the first world conflagration, the elements of mental cohesion of the Transylvanian peasant world were centred on the notions of family, house, parish, village, and 'country'. Moreover, the former border communities of Năsăud also inherited a past marked by respect and obedience towards authorities, enhanced by a sense of protecting individual and collective goods.

The mobilisation order issued in the autumn of 1914 and the departure of men to the frontlines led to the destruction of this circle of security, both for those enlisted and for those left behind, mostly women, children, and elderly. The description made by priest Pamfiliu Grapini to the village of Șant in the aftermath of the war's outbreak remains emblematic: "Houses full of suffering, eight to ten children left without a provider, the land uncultivated, no food, no money. A crying situation only the good Lord can help us out of" (Grapini, 2018, p. 43).

The enlistment in the Austrian-Hungarian Army, in large numbers, of Năsăud peasants was done, as in the case of most Romanians in the Monarchy, at "the order of the Emperor," under "the Emperor's flag." During the four years of conflict, more than 926,000 soldiers were mobilised from Transylvania and Banat (Cârja \& Cârja, 2018, p. 225). According to historians Adrian Onofreiu and Cornelia Vlașin (2017), those who went to the front were asked to fight to death for the country and the Emperor, while those who stayed home were asked to support the leaders and the army towards the defeat of the enemy and the achievement of a great victory alleged by the Empire's centuries of greatness. The people had to believe in the force of the imperial army, to be convinced of the justness of the monarchy's cause, to respect the strict rules and new dispositions, to regularly pay their dues and to be fully devoted to the person of the Emperor.

Gradually, the face of the world known by those who remained at home was irrevocably changed. The uncontrolled increase in the food and cattle prices ("Roughly in September 1914 everything began to be more expensive, food and cattle alike") (Buta \& Onofreiu, 2010, p. 280), famine, hardship owed to the lack of labour force, various and repeated requisitions, the increase in the number of widows and orphans have all contributed to the creation of a new, traumatic reality for the members of the analysed communities. This led to the emergence of negative feelings such as despair, anger, sorrow, uncertainty, fear. The peak of the emotional agony induced by all these changes was represented by the requisition of church bells and, in certain cases, the transformation of schools and churches in military quarters (for example in Sângeorz-Băi; see Sohorca, 2015, p. 45).

Moreover, uncertainty and misinformation were common both amongst soldiers and their families left behind. This situation was induced by the authorities who deliberately manipulated both sides by presenting a false reality. For example, the future notary Grigore Ilișiu, mentioned in his memoirs that, while on leave at home during 1918, he was informed by his father about the real situation of the country "which to us was presented as being very good." On his part, the young soldier described to his family the objective situation of the front, "which they knew to be much more favourable" (Buta, 2015, p. 223).

In the months of October and November 1918, the events precipitated all through the AustrianHungarian Empire and, within the context in which the defeat of the Central Powers became a certainty, the soldiers retreated in disorder, returning to their homelands. The community's priest, Victor Lazăr, noted in the record of the Mureșenii Bârgăului Parish the beginning of the 
end for the dualist monarchy, as perceived at the level of a Năsăud village micro-cosmos: “(...) In the autumn of 1918-without anyone remembering the end of the war, with which we had been used for four years - someone passed by our village and told us there's a revolution. Soon, one or another from the village began to return, saying the same - there's a revolution" (Onofreiu, 2008, p. 47). The events that took place in the Bistrița-Năsăud County in the autumn of 1918 fall within the profile of revolutionary manifestations which occurred throughout the province of Transylvania (Dăncilă Ineoan, 2015, p. 511).

In the addressed area, the first soldiers returned from the frontlines at the beginning of November. Most of them were driven by 'revolutionary' feelings and disobedience towards local authorities. "Soldiers from the frontlines and from all over the world keep on coming." - wrote the priest of Șant - "They all bring ideas of liberty and great revolutions. Instead of pouring their pathos, their poverty, their suffering on the government and the broken regime that have caused this war and kept their peoples burdened, they get their revenge on village officials" (Grapini, 2018, pp. 100-101). The immediate consequence was the emergence of a vacuum of authority amid the withdrawal or banishing of Austrian-Hungarian functionaries and administrative authorities (Onofreiu, 2008, p. 39).

The soldiers brought with them not only the "virus of revolution," but also a much more dangerous virus which would make millions of victims across the world, namely, the Spanish Flu. For example, from the outbreak of the epidemic in October 1918 and until the end of the year, in one of our investigated villages, Rebra, the virus claimed the lives of 53 people -33 adults ( 12 men and 21 women) and 20 children. Less devastating waves of the epidemic also occurred in 1919 and 1920 (Bachiș \& Rus, 2016, p. 98).

In addition to the complications created by the return of soldiers and the 'vacuum of authority' cause by the overthrow of the old authorities, the acute shortage of vital products has made the situation in the Năsăud villages increasingly tense overnight. "Oil [petroleum], flour and other products cannot be found, and the people are shouting and they are right," - wrote Pamfiliu Grapini - "Some people are walking barefoot, while others are walking in wooden shoes. I have never seen such shortages before" (Grapini, 2018, p. 99). The soldiers' anger, corroborated sometimes with that of the common people tired of war and deprivations, was primarily directed towards mayors and notaries, while in some localities even the priests and teachers became a target. These small functionaries were perceived as responsible for the evils of war. Homes, properties, communal goods, forests etc. were devastated.

Two possible explanations for these events should be considered. On the one hand, it was the unleashing of energies and attitudes censored for too long by the political system of the former Monarchy (Onofreiu, 2008, p. 41). On the other hand - the idea supported by historian Liviu Maior - it was the fact that, by the time of demobilisation in 1918, people in general were no longer the same as they had been in 1914: "Other projects, other mentality were born, dominated by new principles, by the idea of the changes that were expected in all fields" (Maior, 2016, p. 19).

The events which took place at the end of 1918 have determined in the Năsăud villages, as well as in all other communities of Transylvania, radical changes regarding the political and national organisation, important decisions being made for the future of Romanians living in the province. Following the establishment of 'Consiliului Național Român Central' [the Central Romanian National Council], with its headquarters in Arad, a directive was issued on November $3^{\text {rd }}, 1918$, on the basis of which national local council and national guards were created in all Transylvanian counties, towns and communes-including the Năsăud villages. 
The national local councils also called national senates/assemblies and the national guards, made of the most trustworthy members of the communities, kept the public order, and prepared the transfer of authority from the old Austrian-Hungarian institutions to the new Romanian ones. This process was gradual, and it took place against the background of the revolutionary effervescence which dominated the entire province. A number of Romanian intellectuals traversed the villages along the Someș Valley, the Bârgău Valley and the Șieu Valley with the purpose of pacifying the population and establishing the aforementioned national councils and guards. As a general remark, a nuance of local specificity can be noticed regarding our addressed area, but nevertheless, a synchronism with the actions carried out at the general level of Transylvania is obvious (for more details see Cârja, 2018).

\section{The transition towards the 'new order'. Case study-the memoirs of PavelTofan}

The memoirs of veterinarian Pavel Tofan reshape the manner in which, at a symbolic level, the mental border between the 'old' and the 'new world' was crossed, concomitantly with the processes of the reorganisation of the Năsăud communities. Written in Cluj in 1959, these memoirs relate the events which took place in Bistrița-Năsăud County before December $1^{\text {st }}$, 1918 , and the act of unification. The focus of our analysis will be on the passages in which the author recounts the atmosphere and sequence of events in the villages of Nepos, Feldru, Ilva Mică, Sângeorz (today the town of Sângeorz-Băi), Maieru and Leșu, all placed along the Someșul Mare Valley.

Immediately after the establishment of the Romanian National Assembly of Bistrița, on November $4^{\text {th }}, 1918$, it was decided to send emissaries ("delegates of the people") to all villages of the county, in order to organise local councils and national guards. Born in Nepos and, thus, knowing the Someșul Mare Valley well, Pavel Tofan became one of the delegates. His firm belief was that "us, the members of the Assembly, feel that the people need to be informed, educated, while their outbursts need to be channelled in the right direction of the historical moment and circumstances, so that this moment could be in the benefit of all" (Salvan, 2008, p. 76).

On November $6^{\text {th }}, 1918$, he began his journey from Bistrița together with Ionel Scridon, Emil Domide and Alexandru Colța, the former two having "their chests pinned with decorations and carrying a large Romanian flag." The first village they reached was Nepos, Tofan's birthplace. There, he asked for the church bells to be rung "într-o dungă" - a special way of ringing a bell with the clapper hitting only one of its sides - so that the villagers would know to quickly gather at the church. After a discussion with the local priest and the teacher, Tofan learned that the notary and the policemen were attacked and chased away from the village, while the two Jewish shops were devastated. The villagers gathered in the church yard where Pavel Tofan delivered a speech urging them to remain calm, to keep the peace and order and "to enjoy together" the changing times that, he emphasised, were beneficial for the Romanian people. Moreover, he asked the village to organise a national guard under the command of the highest ranking of its soldiers. In the end, he requested all those present to vow that henceforth they "would serve solely under the Romanian flag and would abide solely to the word of the National Assembly and His Majesty Ferdinand, the King of all Romanians." Before leaving, the villagers assured him they would keep the peace and no longer resort to revenge (Salvan, 2008, pp. 86-87).

The following village, which Tofan visited on the same day, was Feldru. There, he and his companions found a "great bustle," as the notary, the priest and the teachers had all been chased away from the village. As in Nepos, the church bells were rung "într-o dungă" in order to call the people, who this time gathered at the school. Following the same pattern, Pavel Tofan 
delivered a speech and "without any resistance" he obtained the oath on the national flag. Nevertheless, it is interesting to mention that, despite the syntagm "without any resistance," from the phrasing the author used to chronologically describe the following events we can deduce that the people were in fact restless, distrustful and tense. Tofan noted that, hours after taking the oath, only in the evening, "while talking more with the people (...) they became calmer and went to their homes" (Salvan, 2008, p. 87).

The following destination of the delegate was Ilva Mică, where Tofan again noticed that all intellectuals had run away: the priest, the notary and the teachers. In addition, he surprised many inhabitants of the neighbouring villages devastating the local factory. In Ilva Mică, the bells were rung "într-o dungă" as well and the members of the community, "quite a few," gathered at the church. In his speech, in which he told those present about the purpose of his visit, all while announcing the end of the war, Tofan referred to the principles listed by the American President Woodrow Wilson, based on which "we have the chance to unite with the motherland, which from now on can cradle at its breast all its Romanian children" (Salvan, 2008, pp. 88-89). In his diary, the author of the analysed memoirs associated the moment when the villagers took the oath with one of the fundamental elements of the rural collective mentality-Divinity, which seemed to 'vouch' for the moment in which the mental frontier was overcome:

"As I stood before the altar, the sunrays were shining through the stained-glass windows and pouring out on us and the villagers as if they were the Almighty's blessings pouring out on us. (...) Those poor Romanians, and the elderly in particular, were kissing the soles of my clothes, as they were used to kiss the vestments of the priest when he passed with the Gifts before them, thanking God for having granted them the chance to see with their own eyes the realisation of our secular dream of being all brothers together." (Salvan, 2008, pp. 88-89)

On November $10^{\text {th }}, 1918$, in the afternoon, Tofan reached Sângeorz, a place where devastations had taken place (the town hotel), but where, unlike in other localities, the intellectuals (notary, priests and teachers) had remained. Before the people who had gathered at the school, the delegate gave a speech in which he explained the political context of the moment, addressing those present the same request of swearing allegiance to Greater Romania and to organise their town according to the decisions taken by the National Assembly of Bistrița. This time, in order to influence his audience in the desired direction, Tofan used arguments in which he presented the liberty of the Romanian Transylvanian people as being a ' $\mathrm{gift}$ ' offered to them 'by the great nations' in exchange for which they had to show gratitude through good organisation and obedience towards the new rulers. His arguments reach their goal and the inhabitants of Sângeorz, including the intellectuals, agreed to take the required oath (Salvan, 2008, p. 90).

The following day, on November $11^{\text {th }}, 1918$, Pavel Tofan visited Maieru where, following the same ritual - the ringing of bells - the people gathered at the school and listened to the discourse of the delegate. The arguments employed are not significantly different than those used in the previous days, being focused on the idea that, in order not to disappoint the peoples who sacrificed themselves to "liberate the world," the Transylvanian Romanians had to display "a good, honest and unvengeful behaviour" (Salvan, 2008, p. 91). For the first time since the tour of the National Assembly of Bistrița's delegation had started, Tofan described a short incident generated by the unclear intervention of a former soldier. The man, who interrupted the speaker during his speech, seemed to disagree with the delegate's arguments. However, he refused to give details of his grievances, reason why his intervention bore no negative impact on Tofan's objective, as proven by the fact that all those present took the solicited oath of allegiance. It is worth underlining the manner in which the author described the atmosphere of the crowd during his speech by stating that "all villagers listened with such reverence and 
enthusiasm to what I was saying that one would have been able to do anything with them" (Salvan, 2008, p. 91).

The most representative elements which confirm the existence of symbolic mental frontiers for the inhabitants of the Năsăud region could be found in Tofan's recounting of his visit to Leșu. After finishing his mission in Maieru, on the same day - November $11^{\text {th }}-$ Pavel Tofan reached the aforementioned village. Unlike in the previous locations, the atmosphere in Leșu was noticeably more tense, reality of which Tofan had been warned in advance. There was no need for the bells to be rung, for the villagers were already gathered at the local school when Tofan arrived, led there by the septuagenarian priest Leon Coșbuc, brother of the famous poet George Coșbuc, as well as by the other intellectuals of the settlement. Giving a nearly identical speech as in the villages visited before, with references to the sacrifice of the peoples who had fought in the war and the need to organise national guards and to maintain the internal order in sign of appreciation and gratitude for those sacrifices, Tofan reached the peak of his discourse: namely, the requesting of the oath. For the first time since the beginning of his journey, the delegate's request was met with a categorical refuse expressed by the community's priest. The main argument invoked by the prelate was that the villagers were still bound by the oath of allegiance to Emperor Franz Joseph I:

"We cannot swear any oath to the Romanian flag, nor to King Ferdinand of Romania, because we swore eternal loyalty to Emperor Franz Joseph I- and then he pointed to the Emperor's face, framed as an icon and hung on the wall behind me, above the teacher's desk." (Salvan, 2008, p. 94).

The Greek-Catholic priest's reference to Emperor Franz Joseph, who had died two years before the end of the war, shows the importance the oath of allegiance to the "good emperor" in Vienna bore in the mentality of the simple people. This situation confirms the persistence of certain mental frameworks which, for the inhabitants of the Năsăud lands, proved to be difficult to overcome.

Judging the meaning of the priest's gesture of pointing towards the 'icon' with the Emperor's face in order to emphasise it as the impediment in taking the oath to King Ferdinand of the Romanians, Pavel Tofan understood that the problem was, in fact, symbolic in nature. Thus, he chose to do a surprising gesture of an equal symbolic value. Tofan stood up from his seat, tumed around and, taking the wooden framed icon off the wall, he smashed it on the desk:

"The glass shattered into a thousand shards, the frame broke apart and the face of the old Emperor, printed on special paper, I tore into a thousand pieces, which I blew from my hand towards the public saying that the Emperor - whom the Russians and us had saved from the claws of the Hungarians in 1848 - sold us to those who had nearly strangled him, so that they could strangle us instead. And, so, he did not deserve and was not worthy of us even thinking of him. Besides, he was no longer alive anyway. I said - our ties with the Emperor of Austria and with Hungary are now ripped apart, just as I have torn the image of the Emperor into a thousand pieces." (Salvan, 2008, p. 94).

Thereafter, taking the printed and framed Hungarian anthem off the wall, Tofan did the same with it as with the Emperor's portrait. After these manoeuvres, those present placed their left hands on their hearts and, with the right hands lifted, they took the oath. After ensuring a national guard would be organised in the locality, Tofan returned to Bistrița in order to inform the Assembly "about everything I have seen and done during these three days" (Salvan, 2008, pp. 92-95).

The veterinarian's memoirs confirm the situation of agitation which, at the end of 1918, existed in Năsăud region and was similar to that registered in the entire Transylvanian space. The life in 
the rural communities was dominated by chaos and disorganisation against the background of the Austrian-Hungarian collapse. The 'old order' no longer existed and the common people needed to be told, at their own level and on their own language, about the changes of the world, in order to find new pointers of reference in their reality. The whole context represented the ideal moment for the transition towards the 'new order' represented by Greater Romania. The role of some local leaders, such as Pavel Tofan, who were great speakers and connoisseurs of popular psychology and the local specifics of certain regions, proved to be essential. ${ }^{4}$

In the information offered by PavelTofan's memoirs, it can be noticed that the transition from the old to the new order implied, at the level of the Năsăud rural micro-cosmos, the existence of certain symbolic gestures, similar to the rites of passage. The first of these gestures was that of announcing and calling the members of the community through the so-called ringing of bells "într-o dungă." At that time, the bells were an integral part in the language of the rural communities and ringing the bells as described in these memoirs ("într-o dungă") was done only to announce either a danger for the community, such as a powerful storm, or an important event, such as the visit of the National Assembly of Bistrița's delegation.

A second common element identified in the memoirs was the place of gathering, namely the church or the school, the two most respected and representative institutions in the life of Transylvanian communities. These places offered credibility and official connotations to the delegates' speeches.

The third - and the most important - element was the oath of allegiance to King Ferdinand I, a gesture which should be compared with a "border point," through which the mental transition from the 'old order' to the 'new' - from loyalty for the Emperor in Vienna to that for the King in Bucharest - was made effective. In the case of Leșu, the community coagulated around the strong personality of Coșbuc, its priest, needed even a visual representation of crossing the frontier line by the physical destruction of the Emperor's portrait.

Although not mentioned by Pavel Tofan in his memoirs, another gesture of high symbolism was the blessing of the Romanian national flag. In Bistrița Bârgăului, this event took place in a church where the entire community swore to "defend it from that day onwards" (Buta \& Onofreiu, 2010, p. 282). In the village of Șanț, according to the record of priest Grapini, the blessing of the flag was done on December $1^{\text {st }}, 1918$, at the same time when the unification of Transylvania with the Kingdom of Romania was proclaimed. "The Romanian national flag was blessed, and its significance was explained to the people," the people swore allegiance to the flag, the Gospel and the Cross, sang the Unification song - 'Hai să dăm mână cu mână'5 - and the priest made a short summary of the past and of the persecutions endured by the Romanian ethnics living in Transylvania (Grapini, 2018, pp. 104-105).

Interested in deciphering the identity mechanisms which operated in the 1918 transition from loyalty to the Emperor to loyalty to the Romanian King, Sorin Mitu believes that the Transylvanian peasants' reorientation of loyalties towards Romania was positively influenced by the fact that there was a monarch in Bucharest, just as in Vienna. The author's arguments are centred around the idea that, for hundreds of years, the Transylvanian peasants and soldiers

\footnotetext{
${ }^{4}$ For the territorial organisation of the local councils and national guards, Dionisie Login was sent to visit the villages along the Bârgău Valley, Victor Moldovan those along the Budac Valley, whereas the prelate Grigore Pletosu was sent to Herina, Galații Bistriței and other Orthodox localities. Gavril Tripon, together with Nicolae Anton, went to visit the villages along the Șieu Valley. For more details see Uilăcan, 2008.

${ }^{5}$ Literal translation: "Let's hold hand with hand."
} 
had been accustomed to manifest their support to the Emperor, the main political recipient of their political loyalty ever since the times of Emperor Joseph II (Mitu, 2016, p. 134; Sabău \& Ilovan, 2019). In spite of a decrease in his popularity, during the war years, Franz Joseph I continued to represent a pillar of dynastic loyalty for the Romanian Transylvanians, even the more so for the soldiers and officers who had sworn him their allegiance (Mitu, 2016, p. 138). The events from Leșu represent a proof of the persistence of dynastic loyalty ${ }^{6}$ and at the level of local elites and communities in the Năsăud region even after the sovereign's death.

For the former military border guards' communities of Năsăud, this mental transition from loyalty towards the Emperor in Vienna to loyalty towards the King in Bucharest was finally sealed on May $26^{\text {th }}, 1919$, during the visit of King Ferdinand and Queen Maria to Bistrița, as part of their extensive royal tour in their new province of Transylvania. On this occasion, there was a parade with representatives from the villages belonging to the old lands of the military border guards. At the end of the parade, a company of veterans made by former members of the Second Military Border Regiment marched before the sovereigns. They had the regiment's old flag with them, riddled by bullets, which they had:

"carried with pride and faith, yet with little reward from the Habsburgs. [...] After 100 years of fighting, the old flag was delivered by a peasant named Petrișor, from Năsăud, to His Majesty the King with the mentioning that, under the protection of the old flag, a new regiment should be made of members belonging to the lands of the former military border." (Grapini, 2018, pp. 111-112)

\section{CONCLUSIONS}

The end of 1918 and the first half of the following year represented the definitive departure from the old way of life, the tearing of ties with the well-known authority figures. The former Hungarian administration was replaced with a new Romanian one, the rules previously imposed by Budapest were replaced with new ones issued from Bucharest. The mental frontiers were overcome and a transfer of loyalty from one monarch to another took place.

The existing primary and bibliographic sources allow a truthful chronological reconstruction of the events that happened in the region of Năsăud in 1918, but they do not clearly emphasise the changes at the mental level, in parallel with the process of establishing the local guards and councils. The identification and analysis of these symbolic changes, using the memoirs of Pavel Tofan as a key source, represent the aim of our research.

The analysed document surprises elements of radicalisation in the villagers' attitude, a legacy of the period when the military border was operational. The aforementioned source proves that it was the merit of the local intellectual elite, leaders of the national movement, to have managed to connect the Năsăud communities with the developing political events. Although realising the importance of the moment they were witnessing, the simple common people seemed to be tributary in attitude to the past, as it could be best observed in the case of Leșu. The establishment of the local Romanian institutions was done in parallel with the mental transition

${ }^{6}$ A turning point in the erosion of the Romanian Transylvanians' loyalty to the Emperor in Vienna was the Memorandum of 1892. Emperor Franz Joseph's refusal to receive the delegation and to read the document issued by the leaders of the Romanian Transylvanians - through which they requested political rights for the communities they represented - highly contributed to this ethnic segment's reorientation of dynastic loyalties towards the King of Romania. For more details on the subject of dynastic loyalty, a work of reference is Cole \& Unowsky, 2007. 
from one type of loyalty to the other, where gestures of symbolic value were present. The change of loyalty was irreversible, being encouraged by the general development of events and by the categorical attitude of some intellectuals who took responsibility, in the name of those they represented, for the rift with the past.

According to the historian Adrian Onofreiu, having helped the people cross this mental frontier, the entire energy of the local intellectual elite was channelled towards supporting the Romanian National Councils in taking over the public administration, keeping and protecting the order, as well as supporting the people's effort to freely express their desire to unite with the Kingdom of Romania (Onofreiu, 2008, p. 30).

\section{REFERENCES}

BACHIȘ, Ș. \& RUS, V. (2010). Rebra. Repere monografice [Rebra. Monographic Landmarks]. Cluj-Napoca: Argonaut.

BÂRLEA, E. (2004). Perspectiva lumii rurale asupra Primului Război Mondial [The Perspective of the Rural World Regarding the First World War]. Cluj-Napoca: Argonaut.

BLAURB (2020). Frontieră. Dexonline. Retrieved October 30, 2020, from https://dexonline.ro/definitie/frontier\%C4\%83

BOLOVAN, I. (2015). Primul Război Mondial și realitățile demografice din Transilvania. Familie, moralitate și raporturi de gen [The First World War and the Demographic Realities of Transylvania. Family, Morality and Gender Roles]. Cluj-Napoca: Școala Ardeleană.

Bolovan, I., COJOCARU, GHE., \& TĂMAȘ, O.M. (eds.). (2015). Primul Război Mondial. Perspectivă istorică și istoriografică [The First World War. A Historical and Historiographical Perspective]. Cluj-Napoca: Academia Română, Centrul de Studii Transilvane/Presa Universitară Clujeană.

BUTA, M.G. \& ONOFREIU, A. (ed. and adnotations). (2010). Condica parohiei greco-orientale Borgo-Bistrița [The Chronicles of the Greek-Oriental Parish of Borgo-Bistrița]. In BUTA, M.G. \& ONOFREIU, A. (eds.), BistrițaBârgăului. Contribuții documentare [Bistrița-Bârgăului. Documentary Contributions] (doc. 35, pp. 280-282). Cluj-Napoca: Eikon.

BUTA, M.G. (2015). Memoriile unui gimnazist năsăudean. Notarul Grigore Ilișiu (30 mai 1890-2 martie 1960) [The Memoirs of a Năsăud Gymnasium Graduate. Notary Grigore llișiu (May 30th, 1890 - March 2nd, 1960)]. Arhiva Someșană, series III, XIV, 213-258.

CÂRJA, C. (volume edited and prefaced by). (2018). Constituirea instituțiilor naționale românești în Transilvania [The Establishment of Romanian National Institutions in Transylvania], vol. IV, part of the Construind Unirea cea Mare [The Making of the Great Union] series, coordinated by Ioan-Aurel Pop, Ioan Bolovan, Ioana-Mihaela Bonda, Ana Victoria Sima, Teodor Laurențiu Popescu. Cluj-Napoca: Școala Ardeleană.

CÂRJA, I. \& CÂRJA, C. (2018). Marele Război și redimensionarea loialităților. Români ardeleni și bănățeni după despărțirea de „bunul împărat" [The Great War and the Resizing of Loyalties. Romanians from Transylvania and Banat after the Separation from 'the Good Emperor']. Revista Bistriței, XXXII, 225-232.

COLE, L. \& UNOWSKY, D.L. (2007). The Limits of Loyalty Imperial Symbolism, Popular Allegiances, and State Patriotism in the Late Habsburg Monarchy. Oxford, New-York: Berghahn Books.

DĂNCILĂ INEOAN, A. (2015). Memoria războiului și a revoluției în Bistrița-Năsăud” [The Memory of War and Revolution in Bistrița-Năsăud]. In Bolovan, I., Cojocaru, Ghe., \& Tămaș, O.M. (eds.), Primul Război Monidal. Perspectivă istorică și istoriografică [World War I. A Historical and Historiographical Perspective] (pp. 501512). Cluj-Napoca: Academia Română, Centrul de Studii Transilvane/Presa Universitară Clujeană.

GRAPINI, P. (2018). Cartea vieții sau momentele de eternă amintire începând de la anul 1903 adecă de la edificarea "Sionului Nou" [The Book of Life or Moments of Eternal Remembrance Starting with 1903, namely the Creation of the 'New Synod'], reedited by D. Munteanu. Bistrița: George Coșbuc Publishing House.

HÄMMERLE, C., ÜBEREGGER, O., \& ZAAR BADER, B. (eds.). (2014). Gender and the First World War. New York: Palgrave \& Macmillan.

HORNE, J. (2010). A Companion to the World War I. Oxford: Wiley Blackwell. 
IGNAT KISANOVICI, I.E. (2015). Participare și mobilizare în Transilvania în Primul Război Mondial [The Mobilisation and Participation of Transylvania in the First World War]. Cluj-Napoca: Academia Română, Centrul de Studii Transilvane.

ILOVAN, O.-R. (2009). Tara Năsăudului. Studiu de geografie regională [The Land of Năsăud. Study of Regional Geography]. Cluj-Napoca: Presa Universitară Clujeană.

LEU, V., BOCȘAN, N., \& BEDECEAN, M. (eds.). (2012-2015). Marele Război în memoria bănățeană (1914-1919) [The Great War in Banatian Memory], vol. I-III. Cluj-Napoca: Presa Universitară Clujeană.

LUPȘAN, S. \& ONOFREIU, A. (eds.). (2003). Districtul Năsăud (1861-1876). Contribuții documentare [District of Năsăud (1861-1876). Documentary Contributions]. Năsăud: George Coșbuc Foundation Publishing House.

MAIOR, L. (2004). Românii în armata habsburgică. Soldați și ofițeri uitați [Romanians in the Habsburg Army. Forgotten Soldiers and Officers]. București: Enciclopedică.

MAIOR, L. (2016). Doi ani mai devreme. Ardeleni, bucovineni și basarabeni în război 1914-1916 [Two Years Earlier. Transylvanians, Bukovinians and Bessarabians in the War, 1914-1916]. Cluj-Napoca: Editura Școala Ardeleană.

MITU, S. (2016). Identități moderne în Transilvania [Modern Identities in Transylvania]. Cluj-Napoca: Argonaut.

MORARIU, M. (I.-M.) (2018). „TTara Năsăudului” în timpul Primului Război Mondial. Aspecte memorialistice, socioeconomice și culturale [The Land of Năsăud during the First World War. Socio-economic, Cultural and Remembrance Aspects], vol. I. Cluj-Napoca: Argonaut.

ONOFREIU, A. \& VLAȘIN, C. (eds. and notes). (2017). Războiul din spatele tranșeelor. Contribuții documentare referitoare la județul Bistrița-Năsăud [The War from Beyond the Trenches. Documentary Contributions Regarding Bistrița-Năsăud County]. Cluj-Napoca: Argonaut.

ONOFREIU, A. (2010). Districtul Năsăud (1861-1876) [District of Năsăud (1861-1876)]. Cluj-Napoca: Argonaut.

ONOFREIU, A. (2019). Războiul în mărturii despre cei de „acasă.” Condici parohiale și consemnări oficiale [The War in the Testimonies of Those from 'Home'. Parochial Registries and Official Records]. In Spinei, V., lacob, Gh., \& Nistor, I. (coord.), Istorii ale Marelui Război și ale Unirii de la 1918 (Volum al Congresului Național al Istoricilor Români, lași, 29 august-1 septembrie 2018) [Histories of the Great War and the Unification of 1918 (Publication of the National Congress of Romanian Historians, lași, August $29^{\text {th }}$-September $\left.\left.1^{\text {st }}, 1918\right)\right]$, (pp. 171-183). Iași: „Alexandru Ioan Cuza” University Publishing House.

ONOFREIU, A. (ed.) (2008). Istoria parohiei Mureșenii Bârgăului [The History of the Mureșenii Bârgăului Parish]. In Şular, C. \& Archiudean, D. (eds.), Asociaţia Profesorilor de Istorie din România - Filiala Bistrița-Năsăud [Association of History Teachers from Romania - Bistrița-Năsăud Branch], Bistrița-90 de ani de la Marea Unire [Bistrița-90 Years from the Great Unification] (doc. 1, pp. 43-49). Bistrița: Barna`s.

ONOFREIU, A., PINTEA, I., \& VLAȘIN, C. (2018). Anul 1918 în județul Bistrița-Năsăud. Contribuții documentare [1918 in Bistrița-Năsăud. Documentary Contributions]. Cluj-Napoca: Mega.

PURICI, Ș., MARECI, H., \& VITCU, D. (2005). Frontiere și identități în istoriografia românească postdecembristă [Frontiers and Identities in the Post-Communist Romanian Historiography]. Codrii Cosminului, 11, 171-181.

SABĂU, C.S. \& ILOVAN, O.-R. (2019). Versified Letters during World War I. Identity Affiliations and Coping Mechanisms in the Former Military Border District of Nãsãud. Brvkenthal. Acta Mvsei, XIII. 5, Brukenthalia. Romanian Cultural History Review, 9, 839-852.

SABĂU, C.S. (2015). „Și ne-au făcut din grănițeri, țărani...”. Mentalități colective în satele năsăudene foste grănicerești în a doua jumătate a secolului al XIX-lea ['They Made Us Peasants from Military Border Guards...'. Collective Mentalities in the Former Năsăud Border Villages, in the Second Half of the 19th Century]. Cluj-Napoca: Mega.

SALVAN, A. (ed.) (2008). Pavel Tofan. Memorii din 1918 [Pavel Tofan, 1918 Memoirs]. In Şular, C. \& Archiudean, D. (eds.), Asociaţia Profesorilor de Istorie din România - Filiala Bistrița-Năsăud [Association of History Teachers from Romania - Bistrița-Năsăud Branch], Bistrița-90 de ani de la Marea Unire [Bistrița-90 Years from the Great Unification] (pp. 69-108). Bistrița: Barna`s.

SIMA, A.V. \& MIHALACHE, T.-A. (eds.) (2018). Propaganda and Mobilisation in Transylvania during World War I. Berlin, Bern, Bruxelles, New York, Oxford, Warszawa, Wien: Peter Lang.

SOHORCA, I. (2015). Povestea comunei Sângeorz-Băi [The Story of Sângeorz-Băi]. Edited by C.F. Domide. Cluj-Napoca: Napoca Star.

TĂMAȘ, O.M. (2015). Război și memorie. Scrieri românești despre Marele Război [War and Memories, Romanian Writings about the Great War]. Cluj-Napoca: Centrul de Studii Translvane. 
UILĂCAN, I. (2008). Marea Unire în județul Bistrița-Năsăud [The Great Unification in the Bistrița-Năsăud County]. In Şular, C. \& Archiudean, D. (eds.), Asociaţia Profesorilor de Istorie din România - Filiala Bistrița-Năsăud [Association of History Teachers from Romania - Bistrița-Năsăud Branch], Bistrița-90 de ani de la Marea Unire [Bistrița-90 Years from the Great Unification] (pp. 9-37). Bistrița: Barna`s.

WINTER, J. \& SIVAN, E. (eds.) (1999). War and Remembrance in the Twentieth Century. Cambridge University Press.

WINTER, J. (2006). Remembering War. The Great War Between Memory and History in the Twentieth Century. New Haven \& London: Yale University Press.

WINTER, J. (2014). The Cambridge History of the First World War. 3 vol. Cambridge: Cambridge University Press. 